\title{
Museums, Manga, Memorials and Korean-Japanese History Wars
}

\author{
Jeff KINGSTON*
}

\begin{abstract}
This paper examines why the history wars between South Korea and Japan are intensifying in the $21^{\text {st }}$ century and the prospects for reconciliation. South Korea's history museums promote anti-Japanese nationalism, making it difficult to unshackle the present from the past. In 2014 there was controversy over a Japanese manga exhibit that resonates with broader bilateral disputes over colonial history ranging from the comfort women to forced labor. These battles over the shared past have become internationalized, stoking mutual vilification and jingoistic sentiments.
\end{abstract}

Keywords: South Korea, Japan, museums, manga, comfort women, reconciliation

\section{Izvleček}

Ta članek preučuje, zakaj se spori o zgodovini vojn med Južno Korejo in Japonsko stopnjujejo v 21. stoletju, in tudi možnosti za spravo. Južnokorejski zgodovinski muzeji spodbujajo anti-japonski nacionalizem, zaradi česar je težko osvoboditi sedanjost preteklosti. Leta 2014 se je pojavila polemika o razstavi japonskih mang, ki je odmevala s širšimi dvostranskimi spori o kolonialni zgodovini, ki segajo od žensk za tolažbo do prisilnega dela. Te bitke za skupno preteklost so postale mednarodne, opremljene z medsebojnim obrekovanjem in šovinističnimi čustvi.

Ključne besede: Južna Koreja, Japonska, muzeji, manga, ženske za tolažbo, sprava

\footnotetext{
* Jeff KINGSTON, PhD, Temple University, Japan. kingston@tuj.temple.edu.
} 


\section{Introduction}

The War Memorial of Korea is a sprawling complex in Seoul, South Korea where those who died in the fratricidal Korean War (1950-53) are honored. One approaches the main building across a massive plaza with a towering, carved obelisk in the center surrounded by statues and bas-reliefs of soldiers and refugees, a gripping statue of reunion between two brothers divided by the conflict (the South Korean soldier towering over his frailer North Korean kin), tributes to the sixteen countries that dispatched troops under United Nations auspices and an outdoor exhibit of military planes, tanks and ships just to the right of the main building. The War Memorial has become a contested battleground in South Korea's intramural history wars, conveying an official narrative glorifying and validating the martial past in ways that are subverted by new memories and fresh remembering that have emerged with the end of military rule and rise of democratization. (Choe 2007) The nation's Truth and Reconciliation Commission launched in 2005 has excavated some of the hastily buried, awkward history that exposes the South Korean (and U.S.) military's indiscriminate killing of civilians wrongly suspected of being communist sympathizers. (Morris-Suzuki 2009) Unsurprisingly, the findings of this investigation have not yet been integrated into the War Memorial's more triumphal narrative.

There is a stone tablet at the entrance of the War Memorial plaza proclaiming, "Freedom is Not Free". The irony became apparent just three days before a special exhibit at the War Memorial was to open on the premises on July 12, 2014, with newspaper headlines announcing that the One Piece manga/anime show from Japan was cancelled. Why? Because in this Japanese manga/anime series featuring the adventures of pirates and other outlaws searching for treasure there are some sketchy depictions of the Rising Sun flag - a red center with lines representing sun rays extending outward - that Koreans associate with Japanese militarism and the painful experiences of Japan's colonial rule 1910-45. According to Tsukuba University's Ôsawa Hirotaka there are very few scenes in the manga in which this Rising Sun flag is displayed and more importantly, it is the flag of the protagonists' enemy and therefore not glorified.

In contrast, the same show staged simultaneously during the summer of 2014 was a huge hit in Taiwan (also a former Japanese colony 1895-1945) attracting

\footnotetext{
${ }^{1}$ Interview August 2014. 
100,000 visitors in the first week alone. The promotional campaign emblazoned the Taipei metro in One Piece cartoons, something unthinkable in Seoul's subway given the prevailing sensitivities about the two nations shared history. After all, it wasn't until 1998 that South Korea began to incrementally ease the blanket ban on Japanese cultural products that was imposed following independence in 1945 . (Trends in Japan 2014) In fact, satellite broadcasts and the Internet had facilitated considerable cultural seepage before then, and Korean translations of Japanese manga were widely available and extremely popular, a grassroots rejection of state policy that helped propel the state-sanctioned cultural opening.

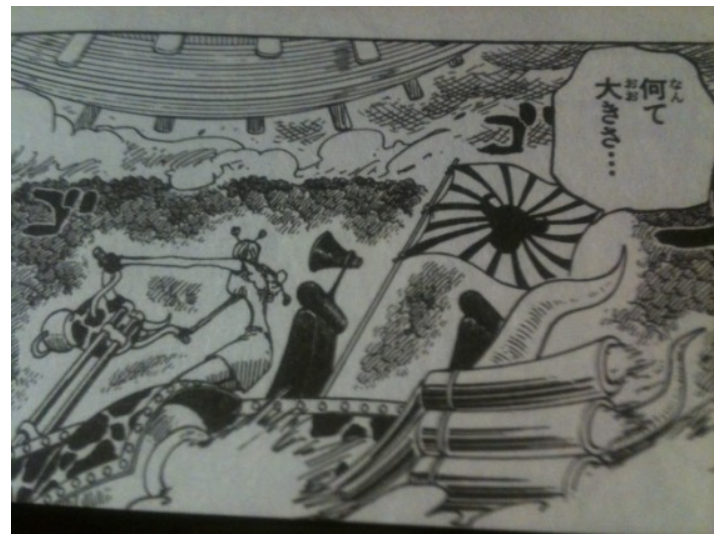

Fig. 1: Enemy vessel with Rising Sun-esque flag approaching the pirate's ship. ${ }^{2}$

There is no denying the popularity of Japanese popular culture among young Koreans who are avid fans of manga and anime and disinclined to see them through the prism of historical animosities or state promoted narratives of victimization because that is not what they are about. This hasn't prevented the ROK government, however, from deploying popular culture in a global battle to win hearts-and-minds. In January 2014, soon after Prime Minister Abe Shinzo's controversial visit to the Yasukuni Shrine in Tokyo on December 26, 2013 that serves as ground zero for an unrepentant, glorifying view of Japanese imperialism, the South Korean government requested that the annual Angoulême International Comics Festival in southwestern France exhibit Korean manhwa (cartoons) about comfort women, the euphemism for women forced into sexual slavery between 1932-45 to provide sex for Japanese soldiers. Most were teenage Korean girls.

\footnotetext{
${ }^{2}$ All photos are courtesy of author.
} 
(Soh 2008) ${ }^{3}$ Among Koreans, Abe is associated with revisionist history that downplays, justifies, valorizes and shifts blame for Japanese imperialism. In his first stint as premier, Abe drew ire in 2007 when he quibbled about the level of coercion used to recruit Koreans to serve as comfort women on March $1^{\text {st }}$, the day when South Koreans remember their anti-Japanese uprising in 1919 and celebrate Independence Declaration Day. The Angoulême organizers turned down a request by the Japanese government to exhibit a Japanese manga about comfort women that supports claims that comfort women were not forcibly recruited by the Japanese military. (ANN 2014) Although this graphic riposte was not displayed, organizers allowed Japanese Embassy staff to pass out pamphlets explaining what the government has done to address the comfort women issue. Strange as it may seem, the realm of cartoons and pop culture is another fiercely contested battleground in the history wars.

Returning to our discussion of One Piece manga, in the seventy-four volumes published between 1997-2013, there are hardly any Rising Sun-esque images and they are not prominently displayed. This is also the case for the 665 thirty-minute anime episodes, 12 movies and about thirty console video games as of 2014 . While One Piece features a lot of violence, meaning the War Memorial site seems an appropriate venue, it has evolved into more than a simple story of pirates' adventures, drawing on Greek and Roman mythology, historical events and contemporary global culture. Some of the themes such as racism, slavery, eugenics, war, justice, social hierarchies and war profiteering speak indirectly to the colonial experience, but there is nothing that specifically relates to Korea's subjugation, and One Piece does not stoke patriotic or nationalist sentiments. It is, however, wildly popular, amassing the highest total manga sales ever in Japan, selling adventure fantasy that pulls in huge crowds, some 800,000 visitors to a 2014 exhibit similar to the ones staged in Taipei and Seoul. Interestingly, the manga is a best-seller in South Korea and hundreds of televised episodes of One Piece dubbed in Korean have been aired in South Korea since 2003 with uncut and edited versions appearing on different channels and until 2014, no controversy over its few scattered images of Rising Sun flags.

\footnotetext{
${ }^{3}$ Soh complicates the issue of victimization and details the range of experiences in ways that undermine popular conceptions of the system by drawing attention to Korean complicity. She is also critical of contemporary advocacy groups that have used comfort women as political pawns.
} 


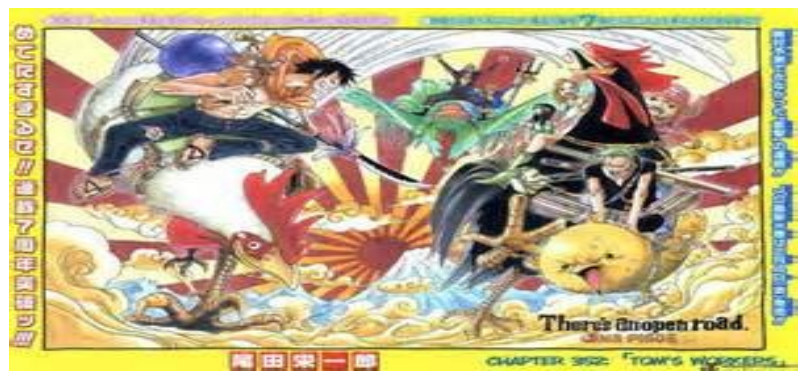

Fig. 2: One Piece Manga episode with offending Rising Sun-esque motif

Netizens in Korea, one of the most wired societies anywhere, have become guardians of public mores and the thought police of the $21^{\text {st }}$ century; some seem to have an obsession with the Rising Sun flag and pressured the War Memorial to cancel the One Piece show over the flag. The back-story of the One Piece saga is that recently there have been a number of cases where K-pop artists have been zinged online for displaying or wearing Rising Sun flag images. (K-pop 2013) Whether as a backdrop for a music video poster, or on designer hoodies and hats, the Rising Sun flag that conjures up images of Japanese imperialism and brutal subjugation among many Koreans seems to have become the East Asian swastika. In a move similar to how Western punk and metal bands tried to cultivate rebellious, transgressive personas by dabbling in Nazi or fascist imagery, use of the Rising Sun flag has become a merchandizing strategy guaranteed to irritate many Koreans and draw attention in a highly competitive field. Given how assiduously K-pop bands are marketed and the extent to which coordinators choreograph everything about their dance routines, appearances, clothing, diet and private lives, it is hard to imagine that such displays were unwitting. But the Rising Sun flag is good copy and, after the attention grabbing ritual apology, the show goes on, hopefully accompanied by rising sales.

Although there were no Rising Sun flag images among the many items in the proposed show, and advance ticket sales had been brisk, War Memorial management abruptly decided to cancel the show at the last minute. Organizers, however, took the case to court and won speedy justice, the judge ruling on July 17, 2014 that the government-run facility was contractually obligated to host the exhibit since it had agreed to rent the space to organizers. The court also ruled that 
One Piece does not glorify Japanese imperialism, perhaps the first legal opinion about the politics of any Japanese manga anywhere. (Asahi 2014) ${ }^{4}$

Soon after the court ruling, Kim Seong Ho, a Korean reporter, pointed out why the flag flap was absurd,

In Korea, it was one of the best-selling manga.... Later on, it was broadcast on KBS, where it also recorded the highest viewer ratings. In particular, the creator of One Piece, Oda Eichiro is known for his strong opposition to Japan's imperialism and militarism, which has often caused controversy in Japan. $($ Kim 2014)

Sora Yang, a specialist in popular culture at Harvard University, believes that the controversy over One Piece demonstrates that, "pop culture is a good deal more revealing than we think it is." ${ }^{\prime 6}$ She believes that the driving factor to cancel the show reflects, "not the power of public sentiment as it is, but the fear of what it might and could be." Japan, as bogeyman, lives on.

The delayed show finally premiered on July 26, 2014 and proved a big hit with Korean fans of Japanese pop culture that flocked to the exhibit whipping out smart-phones to take pictures of the life-size models of the characters on display. So in the end, this tempest in a teapot proved to be good PR with no protests and South Koreans embracing both the rule of law and Cool Japan. Alas, the two countries don't have many of these happy endings to brag of. It's worth pointing out that in May-June 2014 a blockbuster show by Japanese pop artist Kusama Yayoi, "A Dream I Dreamed", further demonstrated that the complex politics of history, and the mutual vilification industry in both nation's media and among netizens, are not always accurate barometers of grassroots sentiments.

\footnotetext{
${ }^{4}$ The newest episode of One Piece serialized in Weekly Jump magazine during 2014 is set sometime in the $19^{\text {th }}$ century, perhaps towards the end of the Tokugawa Era (1602-1858). There is a depiction of a Rising Sun-esque flag with the kanji for wa (harmonious) etched in the center. For Japanese this is an unmistakable reference to Japan, especially as there are samurai silhouettes in the foreground. The pirate protagonists refer to $W a$ as a closed country where the warriors are strong and hostile, making a raid difficult. Ōsawa speculates that perhaps some Koreans are concerned that One Piece might begin valorizing Japanese martial culture and values, but he discounts this possibility because unlike other popular manga, One Piece has consistently eschewed nationalism and patriotism and its main characters are stateless outlaws.

${ }_{6}^{5}$ Sora Yang, a researcher on popular culture at Harvard University provided the link and translation.

${ }^{6}$ Interview August 2014. 


\section{Constructing History}

History museums and memorials serve as repositories of selected memories that provide a window onto defining experiences of a nation. As such they reveal a nation's soul, its anguish, its dreams and traumatic legacies. Problematically, they seek to, "combine the tasks of commemoration and of communicating history", but usually do so incompletely. (Morris-Suzuki 2009) The nationalist narratives on display present a past for contemporary consumption, one that serves political purpose. (Denton 2014) The ghosts of the past that haunt these sites linger in the collective imagination, wraiths and apparitions that kindle shared remembrance and invoke powerful and primordial sentiments. These talismanic shrines to painful experiences and reminders of loss evoke nationalistic passions and promote unifying storylines. They are often sites of collective remembering of traumas endured, portals into the past that impart lessons and promote patriotism.

Yoshida Takeshi, a historian at Western Michigan University and author of "From Cultures of War to Cultures of Peace" (2014), is concerned that the history museums may stoke bilateral tensions and make reconciliation more difficult because they suggest misleadingly monolithic views of denial among Japanese. In his view,

Like their counter parts in China and Japan, elementary, junior high, and high school students visit these museums. While some don't pay much attention to the exhibits, horrifying images of the atrocities may provoke nationalism/nationalistic sentiment among these young visitors. If the visitors in S. Korea know little about different Japanese viewpoints regarding Japan's wartime past, they may simply conclude that militarism has surged in Japan.

In South Korea, it is hard to overstate the power of the state to wield museums as cultural weapons to promote monolithic, collective memories aimed at ramping up nationalism and patriotic devotion. While South Korea accommodates discordant narratives on various issues, public discourse about Japanese colonial rule has not been challenged or undermined by competing interpretations and remains a historical space devoted to the alluring narrative of victimization and un-righted wrongs. By not taking the measure of its shared history with the Korean Peninsula, and tackling the onus of responsibility only episodically, evasively and ambiguously, Japan has handed the hammer of history to Koreans who have, naturally, wielded it with a vengeance. 
In South Korea's history museums, the shared past with Japan features an angry remembering with graphic depictions of suffered endured and atrocities inflicted, thus highlighting unresolved grievances that stoke the embers of resentment and hatred while nurturing a sense of shared degradation mixed with defiant patriotism. Museums and memorials about Japanese colonial rule explicitly nurture a national identity rooted in anti-Japanese nationalism, not only ensuring the odious past is not forgotten, but that it is also mobilized in the present to forge an unassailable common identity of stoic and heroic resistance, sacrifice for the nation and unity. Sophia University historian Sven Saaler argues,

history is first of all mobilized to construct a South Korean national identity, in which Japan is one antipode, but not the only one. Some museums have a somewhat anti-Japanese focus, but overall the main point is to establish a (South) Korean identity. This is a very common phenomenon in modern nation-states and not particularity of Korea at all. ${ }^{7}$

In history museums in China and Korea that focus on Japan, the Japanese depredations are richly and graphically detailed, leaving no doubt about the extent or nature of Japan's heinous crimes. There is no shrinking from the cruelty and savagery of Japanese imperialism. Despite the similarities of history museums in the PRC and ROK, there does seem to be one striking difference. Chinese museums highlight the humiliations endured, sending a contemporary message on the need to be strong. (Denton 2014) South Korean museums don't invoke humiliation, keeping the focus on the barbarity of Japanese colonial oppression and the steadfast, heroic resistance of Koreans. Of course, Chinese museums also feature heroic resistance in the face of Japanese barbarity. This insistence on the gruesome details seems designed to counter Japanese equivocations and disingenuous misrepresentations while stoking anti-Japanese animus. Hatch points out that Chinese museums express a more coherent narrative useful for promoting collective identity than do Japan's war-related museums where competing valorizing and denunciatory narratives are on display. (Hatch 2014)

According to Yoshida, "Chinese and South Korean peace museums tend to differ from their Japanese counterparts in that they often champion nationalism and ethnocentrism in a way similar to Japanese kamikaze and war museums." (Yoshida 2014, 199) While he is right to argue that history museums in South Korea do not encourage reconciliation, it would seem that Japan bears some

\footnotetext{
${ }^{7}$ Interview August 2014. 
responsibility for the stridently accusatory displays precisely because it has not taken the measure of the nations' shared history and thus not addressed the victim's yearning for dignity. Japan has also avoided grand gestures of contrition and reconciliation that are the burden of the perpetrator; it is too much to ask the victim to meet halfway before the victimizer has resolutely and unambiguously accepted responsibility for its misdeeds. Japan has failed this test. Thus South Korean museums and memorials focus on reminding about what the Japanese perpetrated, erecting barriers to improved relations that will no doubt persist because no matter what Japan does it will probably never be enough, thereby ensuring that it will never try enough.

\section{Politics of History}

History haunts and inflames contemporary relations between Japan and South Korea. In an August 2010 speech commemorating the centennial of the Japanese annexation of the Korean Peninsula, then-Prime Minister Kan Naoto said:

The Korean people of that time were deprived of their country and culture, and their ethnic pride was deeply scarred by the colonial rule that was imposed against their will. Those who render pain tend to forget it, while those who suffered cannot forget it easily. To the tremendous damage and sufferings that this colonial rule caused, I express here once again my feelings of deep remorse and my heartfelt apology. (Kingston 2011)

This apology drew a sharp rebuke from current Prime Minister Abe Shinzo and right-wing groups that gathered outside the prime minister's official residence in protest.

In South Korea's fractious society, ethno-nationalism is handy because there are few things that everyone can agree on with the exception of vilifying Japanese colonialism. As such, in democratic South Korea, politicians time and time again play the history card to boost inevitably sagging popularity because confronting Japan plays well in the theater of politics. And, as current President Park Geun-hye fully understands, being seen as soft or well disposed towards Japan is a major political liability that opponents don't shy from exploiting for advantage. Her father, former President Park Chung-hee, is remembered for many things, but his pre-1945 military service in the Japanese Imperial Army and subsequent decisive role in normalizing relations with Japan in 1965 bestow an awkward legacy on Ms. Park, making it extremely difficult for her to insulate contemporary bilateral relations from unresolved historical grievances. (Han 2014) In this 1965 
agreement, the South Korean government accepted $\$ 800$ million in loans and grants in exchange for agreeing that all issues of compensation were settled, closing the door to individual redress with no apology. As such, this agreement has been a longstanding source of controversy in South Korea, a wound that was reopened in 2005 with the release of the archived documents related to the negotiations over the 1965 normalization accord. These documents revealed that the Japanese government had allocated funds for individual redress, but that most of it was diverted to infrastructure and industrialization projects at Park Chunghee's behest.

This duplicity rankled and provides context for the August 2010 ruling by the South Korean constitutional court that the government was violating the rights of Korean comfort women by not making efforts to press Japan for individual compensation. Then in a landmark decision in May 2011, the Korean Supreme Court ruled that the 1965 treaty normalizing relations with Japan does not invalidate claims by former forced laborers and their families for withheld wages. (Kingston 2013) These rulings forced the relatively pro-Japanese government of President Lee Myung-bak to become the unlikely champion for the victims of Japanese colonial rule and helps explain escalating tensions since then. (Dudden 2012) Subsequently, in July 2013, Korean high courts in Seoul and Busan ruled in favor of plaintiffs seeking redress from the recently merged Nippon Steel \& Sumitomo Metal Corp. and Mitsubishi Heavy Industries. The Seoul judge ruled that the companies committed "crimes against humanity" by working with the Japanese government to mobilize forced labor in support of a war of aggression and "illegal" colonial rule. (Kingston 2013)

Despite this rancorous patch in bilateral relations, Tokyo and Seoul nearly finalized a deal on the comfort women, but it unraveled in December 2012. Under the terms of this agreement the Japanese Ambassador to South Korea would have visited the home of each surviving comfort woman and delivered a letter of apology from the prime minister in addition to monetary compensation. The hitch was whether Japan would accept legal responsibility for the colonial era abuses. The Japanese side was willing to accept moral responsibility in making this humanitarian gesture of atonement and reconciliation, but was adamant that it would not accept legal responsibility. Both sides suggest the other is to blame for the last minute failure, one that has sparked bitter recriminations and a sense of betrayal on both sides. Off the record, Japanese diplomats complain that the South 
Korean government moved the goalposts at the last moment, requiring an admission of legal responsibility, when the deal was nearly finalized. ${ }^{8}$ Korean diplomats, also requesting anonymity, argue that a carefully calibrated agreement shirking legal responsibility falls short of the grand gesture required to restore dignity to the comfort women and the nation and therefore could not compromise on this point. Andrew Horvat, a specialist on regional reconciliation issues at Jōsai International University in Japan, believes that the South Korean move was deliberate and, "designed to scuttle the agreement by hard liners on the Korean side who have little to gain from an agreement and everything to lose since their only issue would be resolved." Soon thereafter Prime Minister Abe Shinzo was elected to office, making a deal all but impossible given his apologist views regarding the comfort women system.

Since President Park Geun-hye's inauguration in February 2013 she has insisted that Japan's PM Abe embrace a "correct view" of history before she would meet with him and upbraided a succession of US envoys sent to convince her to soften her stance. She reminded high ranking US officials, including Secretary of Defense Chuck Hagel, that Germany's reintegration into Europe would not have been possible if it acted like Japan in downplaying what it had done and shirking the burdens of history. Abe's visit to Yasukuni Shrine at the end of 2013 vindicated her criticism precisely because it is not just a religious space devoted to honoring the war dead. (Kingston 2007) The US government took Tokyo and Seoul by surprise when it issued a swift and sharp rebuke, expressing Washington's view that Abe was impeding contemporary security cooperation in northeast Asia between its allies and gratuitously stoking regional tensions. Abe has further provoked Korean ire due to his revisionist views on history, especially the orchestrated attempts in 2014 by his party colleagues to discredit the 1993 Kōno Statement in which Japan admitted state responsibility for the comfort women system, apologized for coercive recruitment and promised to atone. (Morris-Suzuki 2014)

Finally, at the insistence of the US, more than a year after Park took office, she met Abe in the Netherlands in March 2014 on the sidelines of the Nuclear Security Summit. To pave the way for the meeting the US had prevailed on Abe to publicly declare that he would not overturn the 1993 Kōno Statement, a "just enough"

\footnotetext{
${ }^{8}$ Interviews Tokyo 2013-2014.

${ }^{9}$ Interview August 2014.
} 
gesture that fell well short of what Park means by "correct", i.e. unequivocal acknowledgement of Japan's burden of history on the Korean Peninsula. Unsurprisingly, this trilateral meeting of heads of state was a frosty gathering with minimal dialogue on the issues that divide.

While South Korean public opinion polls support improvement in bilateral ties, and business leaders are especially keen to do so, it remains politically tricky between these "frenemies". Due to the sharp shift in the region's economic epicenter to China over the past decade, and South Korea's burgeoning trade relations, there is growing concern about Beijing's expanding influence reminiscent of the vassal state relations that prevailed until the $20^{\text {th }}$ century. In this context, maintaining good ties with the US and improving relations with Japan is seen to be a prudent hedging strategy. But Park's paternal legacy leaves her vulnerable on Japan, and is a major factor in why she has taken such a hard line on history.

\section{Comfort Women Remembered and Internationalized}

Japanese reactionaries have been eager to turn the page on the shared past before it has been read, while South Koreans show no inclination to forgive or forget the traumas experienced at that time. No issue is as divisive as the "comfort women" system that involved Japanese military and government complicity in the coercive recruitment of tens of thousands of young women, mostly Koreans, to serve in military brothels. The Japanese Diet formed a committee in 2014 that conducted research and released findings aimed at discrediting the 1993 Kōono Statement by depicting it as a political compromise between the governments, a diplomatic olive branch and gesture of goodwill rather than a historically documented and accurate appraisal. It was due to the Kōno Statement that the government supported establishment of the Asia Women's Fund (AWF), launched in 1995 and terminated in 2007. The AWF offered compensation and letters of apology signed by the prime minister, but because it was an equivocal gesture sidestepping the state's legal responsibility, it did little to promote reconciliation. (Kingston 2010, $198-205)^{10}$

Subsequently, a South Korean nongovernment organization commissioned a statue of an Asian girl barefoot in traditional dress, sitting next to an empty chair,

\footnotetext{
${ }^{10}$ Perhaps the greatest legacy of the AWF is a digital museum about the comfort women system. It is available in Korean, Japanese and English.
} 
her gaze fixed eerily in silent rebuke across the street on the Japanese Embassy in Seoul. The bronze statue was unveiled in December 2011 to mark the $1,000^{\text {th }}$ weekly protest by a dwindling number of comfort women; only 55 remain alive as of mid-2014. Former President Lee Myung-bak (2008-13), South Korea's most pro-Japanese leader since Park Chung-hee, grew so exasperated with Japanese intransigence over the comfort women and forced labor issues that he threatened to place additional statues on the site.

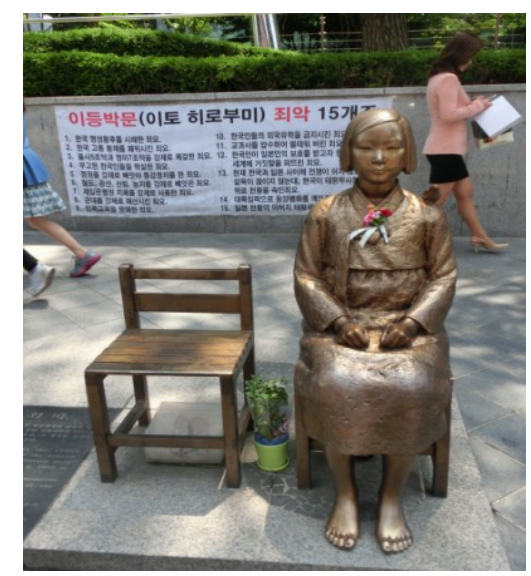

Fig. 3: Comfort Woman statue in Seoul across from Japanese Embassy

The internationalization of the comfort women controversy has simmered in UN human rights committees and in dueling op-eds around the world, but now there are overseas efforts to create tangible memorials that commemorate the women's suffering and cause considerable discomfort among Japanese government officials and conservatives. Since 2010, four towns in the U.S. have unveiled comfort women monuments that have drawn angry protests by conservative Japanese politicians.

The comfort women monument movement in the US is directly linked to PM Abe's 2007 comments quibbling about the level of coercion involved in recruiting Korean women. There is a perception in the US, driven by $21^{\text {st }}$ century human rights and gender equality norms and values, that too many Japanese politicians are in denial about the comfort women system and demonstrate insufficient contrition. In response, Korean-American groups have played a role in lobbying and fundraising to commemorate the suffering of comfort women. In 2010 Palisades Park, New Jersey where more than half of the population is Korean American, became the first municipality to erect a comfort women memorial 
despite intense lobbying by Japanese diplomats not to do so. There is also a comfort women memorial in Nassau County, New York at the Veterans' Memorial in Eisenhower Park.

On 2013 Glendale, California unveiled a statue identical to that in Seoul that is placed in the town's public park. (Levine 2014) It did so on July 30, the day the town council has designated Comfort Women Day. A Japanese-American woman resident in Glendale together with a Los Angeles based nonprofit group that campaigns against the comfort women redress movement, sued the town of Glendale in California. The lawsuit filed in the US District Court in Los Angeles argued that the town of Glendale, by erecting the statue, infringed on the federal government's right to conduct foreign affairs and demanded that it be removed. The plaintiffs also argued that the Japanese government was not involved in sexual slavery, claiming that, "by installing the public monument, Glendale has taken a position in the contentious and politically sensitive international debate concerning the proper historical truth of the former comfort women." Although the Glendale council approved installation of the statue, the lawsuit alleges that the text of a plaque adjacent to the monument regarding the history of comfort women was not reviewed and approved in violation of the city's code. The plaque dedicates the monument to the memory of 200,000 comfort women from all over Asia while imploring the Japanese government to accept responsibility for its role in the system. The plaque also explains that the adjacent empty chair, "symbolizes comfort women survivors who are dying of old age without having yet witnessed justice." (Johnston 2014)

In August 4, 2014 the judge dismissed the lawsuit and the plaintiffs' demand to remove the comfort women statue. The judge also confirmed that, "the statue is entirely consistent with the federal government's foreign policy." That same day the town of Union City, New Jersey became the fourth in the US to establish a comfort women memorial.

Sven Saaler, professor of Japanese history at Sophia, doesn't think that the new memorials represent a significant change because,

The issues at stake are the same. Building memorials is just an attempt to set something in stone, quite literally. Previously, appeals to the international community were made through criticizing textbook contents or visits of politicians in Japan to certain memorials. Now memorials are built in order to 
appeal to the international community, but the original intent and the issues at stake have not really changed. ${ }^{11}$

Yoshida, professor of history at Western Michigan University, comments,

Politics, power, economy, justice, and national identity are probably the reasons behind the internationalization of Japan's wartime atrocities. To many Americans, forcing women into sexual slavery is a violation of human rights, and it is no surprise that many of them support building the memorials dedicated to these women. Many Americans are probably unaware of violations of women's rights around the US bases in the world, though. The PRC and the South Korean government seem to have been using the past to unite the nation, too. ${ }^{12}$

While Japanese conservatives allege that Korean-American groups are orchestrating this anti-Japan campaign, Mindy Kotler, director of the Washington D.C.-based Asia Policy Point, comments,

Koreans are coming of age politically in the U.S. They are practicing "retail politics" as every ethnic group in the U.S. has. They are not doing anything different than the Irish, the Armenians, the Jews, or the Greeks. It's a Japanese worldview that sees this as an effort to embarrass Japan. It is not viewed that way here, only as standing up for your heritage. (Johnston 2014)

Following a brief visit to Tokyo in April 2014, President Barack Obama visited Seoul where he condemned Japan's "comfort women" system as

a terrible, egregious violation of human rights. Those women were violated in ways that, even in the midst of war, was shocking. And they deserve to be heard; they deserve to be respected; and there should be an accurate and clear account of what happened. I think Prime Minister Abe recognizes, and certainly the Japanese people recognize, that the past is something that has to be recognized honestly and fairly. (White House 2014)

It is interesting that Obama only "thinks" Abe gets it, implying he may not, while he knows the Japanese people understand the moral demands of historical responsibility. Clearly, Abe remains behind the eight ball of revisionist history in part because he has eroded trilateral trust between Washington, Seoul and Tokyo and not made any gestures that address this pain or the victims' search for justice and dignity. (Togo 2014) Indeed, in August 2014 Navi Pillay, the outgoing United Nations High Commissioner for Human Rights, lamented that Japan, "has failed to

\footnotetext{
${ }^{11}$ Interview August 2014.

${ }^{12}$ Interview August 2014.
} 
pursue a comprehensive, impartial and lasting resolution" to the comfort women issue and was critical of the 2014 Diet inquiry by conservative lawmakers intent on debunking the 1993 Kōno Statement. (Pillay 2014)

As Alexis Dudden, professor of history at the University of Connecticut observes,

In the internationalization of history, the story of the sex slaves has resonated most and rightly so. This is why Japan now finds itself again receiving censure from the UN Human Rights Commission: just what doesn't Abe "get" about the term "slavery"? For the Japanese government, this is not just a losing story, but beneath the nation's dignity. It's also why the surviving Korean sex slaves' decision to use any money gained in the future for an international fund - they set it up 2 years ago - is telling: the victims teach the rest of us that truly awful histories are by definition international once they are learned as history. ${ }^{13}$

\section{Ahn Jung-geun: Awkward Avatar of Anti-Japanese Nationalism}

To defend the Orient one must improve (or change) one's strategy. The time to act is now, otherwise all will be lost.

欲保東洋 先改政略 時過失機追悔何及 ${ }^{14}$

Japan is worried that China and South Korea are ganging up on it over history, pointing to the memorial hall unveiled at Harbin Station in north-eastern China earlier this year honoring Ahn Jung-geun, the South Korean independence activist who in October 1909 assassinated Itō Hirobumi, a prominent Japanese statesman closely associated with Japan's annexation of the peninsula. (Rausch 2013) This memorial was suggested by Park in the summer of 2013 and taken up by Chinese President Xi Jinping, attesting to warming bilateral relations at the expense of Japan.

Historian Sven Saaler points out that,

statues to independence fighters that were active in a transnational setting are nothing unusual, so the Japanese claim that the building of this memorial was a one-sided interpretation of history is not only incorrect, it is also inappropriate and hypocritical given the extremely one-sided interpretations

\footnotetext{
${ }^{13}$ Interview August 2014.

${ }^{14}$ Ahn Jung-geun Memorial Hall website, translations by Yun Hyun Sook. 
of East Asian history advocated by members of the current [Abe] administration. ${ }^{15}$

"We recognize Ahn Jung-geun as a terrorist who was sentenced to death for killing our country's first prime minister," said Suga Yoshihide, Prime Minister Abe Shinzo's chief Cabinet spokesman in January 2014.

In reply to Suga, Chinese Foreign Ministry spokesman Qin Gang stated: “Ahn Jung-geun is, in history, an upholder of justice who fought against Japan's aggression. If Ahn Jung-geun was a terrorist, what about the 14 Class-A war criminals of World War II honored in Yasukuni Shrine?" For Koreans this "terrorist" is a national hero and patriotic martyr who gave his life for his nation, a narrative of dying honorably, a model of ultimate sacrifice to inspire contemporary Koreans.

In a triumph of chutzpah over history, Ahn's legacy has been repositioned in light of contemporary political and diplomatic battles. (Denney and Green 2014) Although he was a passionate advocate of Pan Asianism under Japanese leadership - a form of collective self-defense against western imperialism- he has been transformed for contemporary purposes into an exemplar of anti-Japanese nationalism. In this narrative, his act of assassination takes center stage while his Pan Asian writing and advocacy of regional unity and cooperation are marginalized.

In the heart of Seoul, Ahn has long been honored as a national martyr and hero with a far more extensive memorial hall than that in Harbin. Tōgō Kazuhiko, former Japanese ambassador to the Netherlands and grandson of wartime Foreign Minister Tōgō Shigenori (one of the Class-A war criminals enshrined at Yasukuni Shrine), once told me that he abhorred the assassination, but grew to admire Ahn upon learning about his Pan-Asiatic views at this museum. Ahn wanted to forge a united response among Asians to Western imperialism and viewed Japanese colonialism as a betrayal. He held Itō Hirobumi personally responsible for this treachery because he drew up the 1905 Eulsa Treaty that made Korea a protectorate of Japan with the acquiescence of the western powers following Japan's victory over Russia. (Dudden 2005) Subsequently, Japan engaged in a devastating scorched earth policy to subdue resistance that led to annexation in

\footnotetext{
${ }^{15}$ Interview August 2014.
} 
1910. Ahn was executed on March 26, 1910 before completing his "A Treatise on Peace in the East", a call for regional solidarity to resist western imperialism.

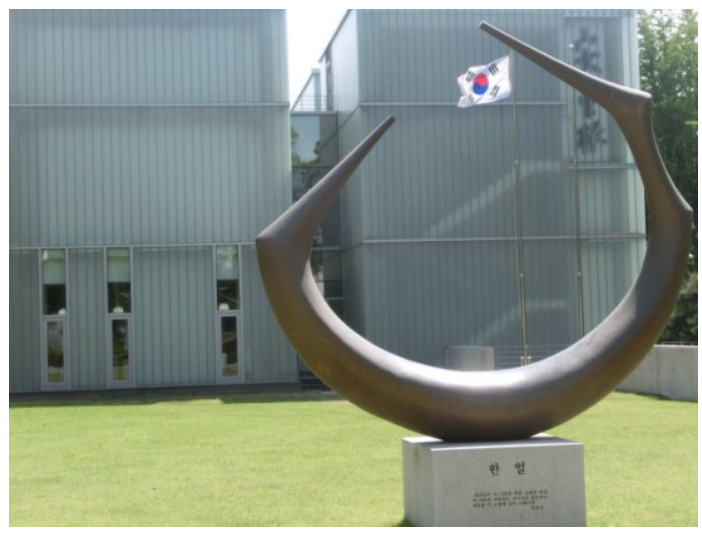

Fig. 4: Ahn Jung-geun Memorial Hall

To commemorate the centennial of Japanese colonization, the sleek new Ahn Jung-geun Memorial Hall on the hillside of Namsan Park in central Seoul reopened in 2010, replacing the museum built there in 1970. This iteration is designer chic, a series of twelve translucent cubes edged by a shallow moat nestled in a grove of trees. The dozen cubes symbolize the number of unsung heroes who participated in Ahn's Society of Patriots. As Ahn was Catholic, it is striking that the number corresponds to the number of apostles.

The entrance is a downward sloping ramp flanked on the right by a wall etched with Ahn's calligraphic messages and handprints, all missing his ring finger that was cut off to provide blood as a substitute for ink when inscribing a flag with the characters for "Korean Independence". These messages were originally written while Ahn was imprisoned after being arrested for the assassination. They include quotes on morality and loyalty from the Confucian Analects and other Chinese classics and as such constitute cultural weapons, a way for Ahn to continue his struggle and convey his message even while incarcerated. (Wakabayashi 2008) They are signed-Ahn Jung-geun "Citizen of Great Korea". Some were written for a Japanese prosecutor ("Seriously worrying and thinking about the safety and crisis of the country” (“國家安危労心焦思”) and a Japanese guard (“The devotion to the country is the serviceman's duty” (“為國獻身軍人本分”) that were returned to the South Korean government by the families of the original recipients. Ahn seemed to win the grudging respect of Japanese officials during the five month imprisonment before his execution because of his dignity and 
religious piety, a remarkable turn of events given that he had killed one of Japan's national heroes. One of Ahn's own poems on display reads: "Every year the same flowers bloom, but the people change with the passing of time" (年々歳歳花相以、 歳歳年々人不同).

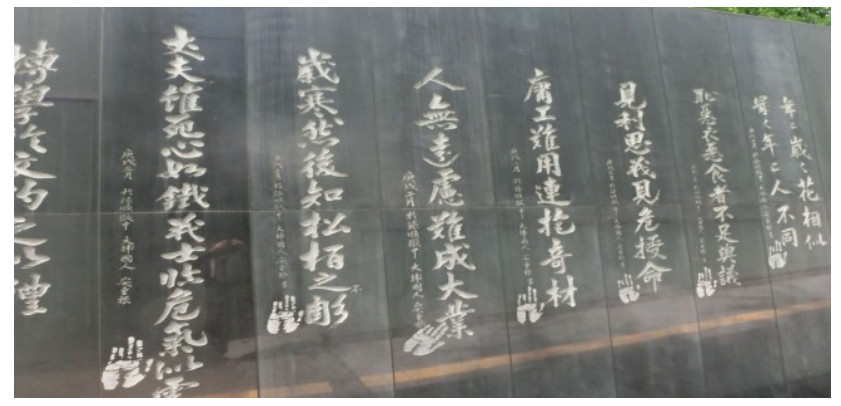

Fig. 5: Ahn's distinctive handprints and calligraphy adjacent to entrance ramp

Spread over three floors, the exhibits honor Ahn as a "patriotic martyr" and are brimming with nationalistic symbols, none more compelling than the massive Korean flag hanging behind Ahn's statue in the spacious gallery close to the entrance, one that is festooned with his bloody calligraphy spelling out "Korean Independence". There is a dramatized reenactment of the assassination and subsequent courtroom scene, the pistol used in the shooting, a replica of his severed ring finger and even an Ahn anime room. The museum highlights Ahn's background and participation in the pro-independence movement against Japan as his Pan Asian thoughts are overshadowed by displays devoted to his patriotic activism and the assassination.

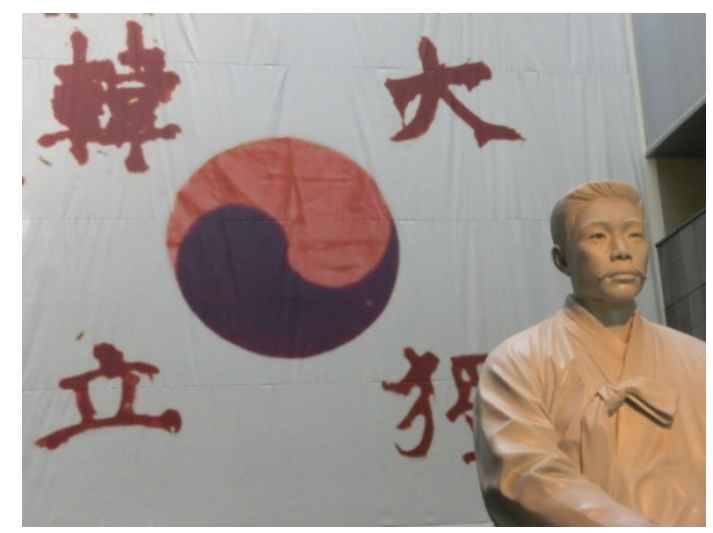

Fig. 6: Korean flag with Ahn's bloody calligraphy declaring independence 
Interestingly, the museum is located on the site of Chōsen Jinguū, the Shinto shrine built by the Japanese in 1925 and dedicated to Emperor Meiji and Amaterasu, the Sun Goddess of Japanese mythology. It was demolished after independence in October 1945 because it symbolized Japanese cultural imperialism and efforts at Japanization. (Han 2014) From 1925 Korean elementary and middle school students were required to attend Shinto Shrines (there were 1,140 scattered over the peninsula as of 1945) where the Japanese Emperor was venerated, and from 1935 such attendance was also compulsory for university students and government employees. (Wakabayashi 2008) This spiritual space once devoted to imperial veneration is now re-consecrated as a locus of colonial condemnation.

Denney and Green (2014) argue,

While Koreans and Chinese remember Ahn as a heroic independence activist, many Japanese will continue to see him as a terrorist, pure and simple. And while South Korea has by and large moved beyond the fissures of its contentious past, the divisive history of figures like Ahn are a stark reminder that legacy politics in the region continues to fan the flames of conflict, and seems set to do so for many years to come.

Ahn is heavily politicized and frequently instrumentalized to justify and bolster an anti-Japanese sentiment that he did not share. Franklin Rausch argues that,

a survey of An's writings and his interrogation and trial transcripts turns up little that is anti-Japanese in this broad sense. In fact, An invariably referred politely to the Japanese Emperor and avoided criticism of the Japanese people and government as a whole. (Rausch 2013)

Donald Keene, who wrote a biography of Emperor Meiji, asserts that,

An was not anti-Japanese. The man he most admired was undoubtedly Emperor Meiji, and one of his most vehement accusations against Ito Hirobumi was that he had intentionally deceived the emperor, who desired not the subjugation of Korea but peace in East Asia and Korea independence. An was delighted to read about Japanese victories over the Russians and claimed that his compatriots shared his joy over the defeats suffered by one of the agents of White Peril. He regretted only that Japan had broken off the war before Russia was reduced to total submission. (Keene 2002, 664)

Killing Itō was about exposing his lies in the hope this would lead the Meiji Emperor to reform Japan's policies in Korea. The self-styled "righteous soldier" fighting the "righteous war" erred in thinking that his death would spark a rational 
reconsideration of Japan's colonial project in Korea. Little could he imagine that he would subsequently be drafted to serve as patron saint for "righteous" antiJapanese agitation in the $21^{\text {st }}$ century.

Keene notes,

An still hoped that relations between the two countries would become closer, providing a model for the whole world to imitate. An urged a sympathetic Japanese prosecutor not to worry about whether or not he would be condemned to death. (Keene 2002, 664)

Rather than being virulently anti-Japanese, Ahn proposed a loose confederation between China, Korea and Japan, a Pan Asian vision advocating trilateral cooperation and autonomy. Ahn expected Japan to take the lead since it was the most advanced of the three nations and could promote successful modernization in East Asia. But this is not the Ahn the contemporary state needs so his shooting Itō to death is highlighted at the expense of his desire for Pan Asian cooperation.

\section{History Imprisoned and Unshackled}

The seven red-brick buildings of the Seodaemun Prison History Hall look more like an old factory complex than an infamous colonial-era prison where the Japanese government in Chōsen (the colonial name for Korea) incarcerated and tortured anti-colonial activists and political agitators.

The prison facility now serves as a museum featuring dark cramped cells, replete with scenes of torture and canned screams of pain. ${ }^{16}$ One sign proclaims: "Torture-A Tool for Ruling the Colony". We learn that water and fingernail torture, and savage beatings, were common practice in the underground torture chamber where prisoners were interrogated. To intimidate them, they were kept waiting their turn in an adjacent "temporary detention room" so they could hear the sounds of torture and moans of pain, and anticipate what lay in store.

It is an unnerving space of cruelty, a crypt for the hidden horrors of the colonial past. The wooden isolation cells resemble standing coffins that visitors can step inside to experience the claustrophobic experience as a companion secures the door. Perhaps the most riveting feature of the facility is the possibility of having one's picture taken and digitally inserted onto the face of a prisoner undergoing torture. There is also a table where one can sit hooded wearing a

\footnotetext{
${ }^{16}$ I visited in 2009 before extensive renovations and again in 2014.
} 
wicker basket, arms extended and manacled at the wrists, reenacting how the fingernail torture was administered.

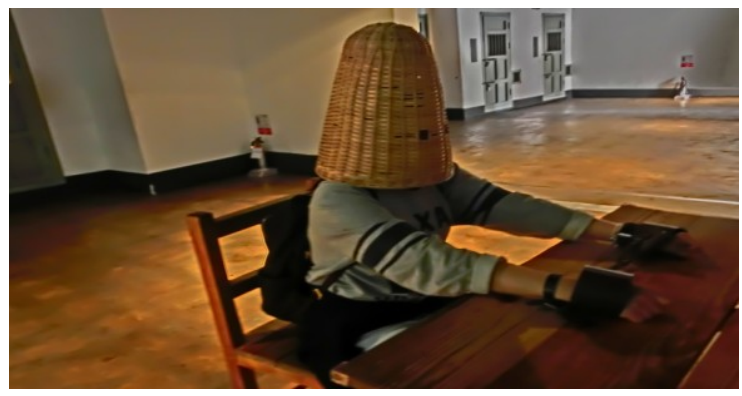

Fig. 7: Fingernail torture

Seodaemun was the largest of sixteen prisons built throughout the peninsula in 1908, "with the aim of suppressing the Korean patriots who were fighting to regain national sovereignty." Renovated in 2010 for the centennial, the Seodaemun exhibits now convey more about the colonial era history, explaining for example that the space of the facility was expanded thirty-fold in the 1930s to accommodate the increased number of Korean independence activists. Established with a capacity for 500 prisoners, by the end of the colonial era Seodaemun housed 23,532. At that time there were 261 warders, Korean employees referred to as "faithful first-line puppets"; before the 2010 renovation the delicate topic of colonial collaborators was not raised. The museum explains that on average there were, " 30 or so prisons in each city, making the country like a huge prison."

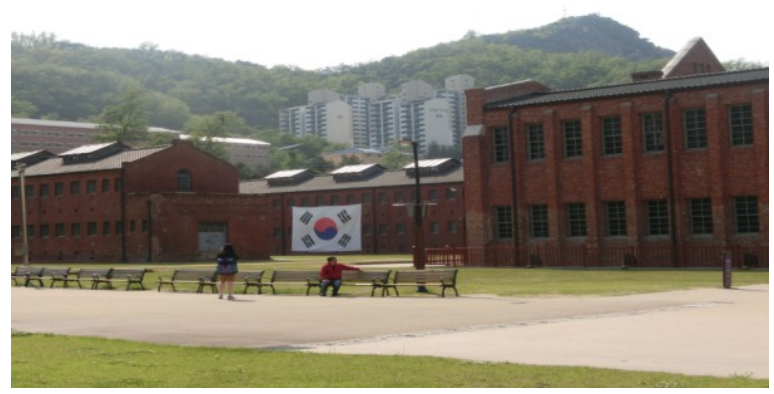

Fig. 8: Seodaemun Prison

Unlike in China, there is no dwelling on national humiliation. In the National Resistance Hall of the museum visitors learn, "the Korean people were never frustrated about the annexation but actively launched independence movements." It is a story of brave and unrelenting resistance by staunch patriots despite Japan's, 
"harsh colonial rule, making Koreans fall into a state of slavery and frantically trying to liquidate Korean culture and language." It was an "incessant struggle" in which "the whole of Korea" participated, except for the many collaborators. A display about the "heroic struggle" notes that activists targeted Japanese and proJapanese Koreans, complicating the valorous narrative with collaboration.

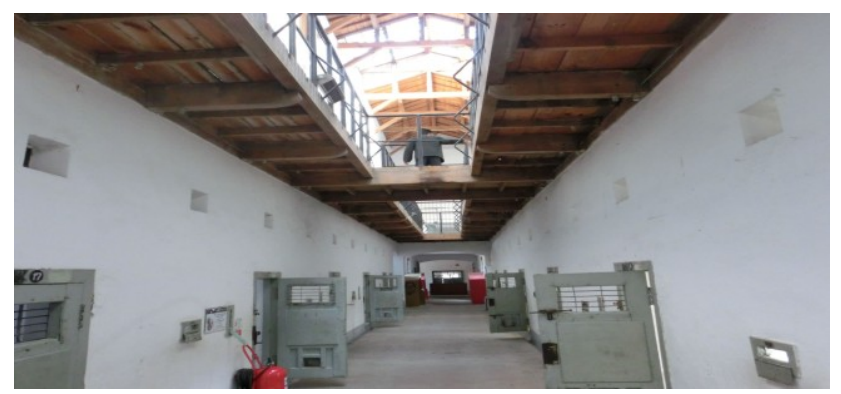

Fig. 9: Cell-block where post-independence, pro-democracy political prisoners were held

Although unacknowledged in the museum's pamphlet, the museum has tackled the controversial use of the jail to incarcerate a new generation of dissidents by South Korea's military regimes from the 1960s-1980s, thereby linking the pro-independence and pro-democracy struggles as well as the Japanese colonial and ROK military regimes. There are several cells on one corridor with displays featuring the stories of these post-independence political prisoners although after the 2010 renovations one can no longer see the messages these prisoners scratched onto the walls. One plaque explains that the prison was operated until 1987, where, "many democratization activists during the despotic regime after liberation were imprisoned, tortured and died."

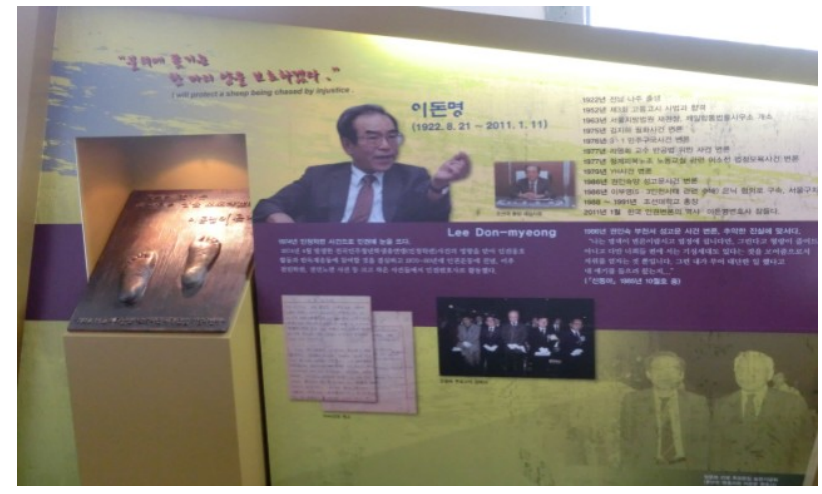

Fig. 10: Cell-block with dioramas about ROK political prisoners 
So the post-2010 version of Seodaemun embraces a more controversial history, complicating what had been a straightforward prosecution of the Japanese by implicating Koreans in collaborating with the colonial regime as warders and therefore part of the colonial system of subjugation. Moreover, the museum now tells the previously untold story of the prison's role in the suppression of the prodemocracy movement, a place where political prisoners opposing a succession of Korean authoritarian regimes were jailed, tortured and killed. In that sense Seodaemun has become a powerful symbol of resistance against the $20^{\text {th }}$ century arc of tyranny that engulfed the peninsula, connecting colonial and independent Korea, underscoring the painful evolution from an oppressed nation to its democratic flowering since the denouement of military rule at the end of the 1980s. The indictment of the ROK military, forced now into the dock alongside the nefarious Japanese, is a bold statement signaling just how far democracy has come. But, the pain persists because like the Japanese, South Korea's military henchmen have not been held sufficiently accountable and won't be.

\section{Resilient History Wars}

Nearly seventy years after the end of Japanese colonial rule on the Korean peninsula in 1945 the legacies continue to reverberate angrily within both countries and between them. Prospects for reconciliation between these frenemies seem remote because on too many issues concerning the shared past there is little common ground between what Koreans insist on and what conservative Japanese are prepared to acknowledge. The failure of the AWF (Asian Women's Fund) to heal wounds and the last minute collapse of a deal on the comfort women at the end of 2012 represent missed opportunities. Paradoxically, these reconciliation initiatives provoked considerable bitterness, leaving scar tissue on both sides. Clearly the onus of history is on Japan to address the maimed dignity of its Korean victims, but reconciliation initiatives also require Koreans to enable Japan to regain dignity; otherwise there is insufficient incentive to proceed.

For many Japanese the history wars are about humiliating Japan and this has sparked an anti-Korean backlash. The Japanese media has cashed in on (and fueled) the "anti-Korea" (kenkan) boom, churning out hate mongering stories in the weekly magazines. (Schreiber 2013) Nationalist anti-Korean manga are also quite popular. (Sakamoto and Allen 2007) This media frenzy has also spilled over into street protests by racist/anti-immigrant groups such as the rightwing Zaitokukai that harass ethnic Koreans, calling on them to leave Japan and threatening to kill 
them if they don't. (Dudden 2010) Korean schools have also endured hate speech barrages by such xenophobic Japanese groups, although the courts have levied fines and issued injunctions. The vast majority of Japanese repudiate this harassment and there have been larger counter demonstrations, but contemporary Japan, viewed from South Korea, can appear ominous, especially given that PM Abe espouses jingoistic views and is closely associated with the distortions and misrepresentations of revisionist history. He also appointed like-minded cronies to the board of NHK, Japan's quasi-state broadcaster. Momii Katsuto, Abe's handpicked chairman of NHK, downplayed the comfort women issue at his first news conference in January 2014, suggesting that South Korea was always "raking over old ashes" in asserting demands for further compensation.

Viewed from South Korea, this looks like the same old story of denial and downplaying, a narrative that stokes anti-Japanese nationalism. Korean museums, as we have seen with the One Piece manga brouhaha, are sites of these history wars and also serve as repositories for various unresolved grievances and the mobilization of the painful past to whack Japan, thus inciting rage and indignation in both nations. This cycle of mutual recriminations over shared history is not unique or inevitable, but has proven remarkably resilient. Korea's history museums confront the logic of reconciliation with narratives that reduce history to a zero sum game, edifices of memory that reject reconciliation. As such they are tangible symbols of reproach to those who seek to free the present from the dungeon of the past.

Problematically, both the Japanese and Koreans have good reason to cling to their mutual recriminations and vilification because it stokes a useful nationalism. In Japan, Abe fans nationalistic sentiments to promote his patriotic agenda while South Korea seeks to keep Japan wriggling on the hook of history. For Seoul and Tokyo, thus, the upside of reconciliation appears limited.

Many Japanese are exasperated by the history wars because in the seven decades since defeat, Japan has been a force for peace and prosperity in Asia. While this positive record counts for little in South Korea, it is not only jingoistic Japanese who feel that Japan's positive contributions and relatively exemplary record should earn it some kudos rather than what has become ritualized vilification. Japanese may indeed feel perpetrator's fatigue, tired of being blamed for pre-1945 events, but this is not a compelling argument for ignoring a tragic past that remains poorly understood by many Japanese. Japan is certainly not alone 
in wishing away its historical burdens or banishing them to the margins of mainstream narratives. Indeed the Germans are remarkable for not averting their collective gaze from the worst their nation was capable of while the Japanese stand with much of Europe and the U.S. in shirking responsibility and falling short on gestures of atonement and reconciliation.

The sense of being victimized by its history of victimizing is nonetheless extraordinary among conservative Japanese. From their perspective, Koreans are playing the history card to wheedle concessions and compensation from Japan. In this kaleidoscopic view of history, what Japan did then pales in significance relative to what it is being asked to do now. Naturally, Koreans don't see it this way and remain insistent about reminding Japan about past horrors because it seems too eager to move on. Saaler explains, "The manipulation of history for nation-building purposes is, of course, not unique to South Korea; it is what every nation does and is what modern nationhood and nationalism are rooted in...statesanctioned myth-making." 17

Overall, in Japanese museums, textbooks and popular narratives, what was endured overshadows what was inflicted during the 1895-1945 period of Japanese imperialism. (Dower 2012) ${ }^{18}$ It's not that this suffering cancels the debts, or creates a reassuring moral equivalency, but rather the collective gaze is drawn inward and eyes are averted from the colossal crimes of Japanese imperial expansion. Instead, Pan Asianism is invoked to reassure that whatever happened overseas was done with good intentions, driven by the noble mission of liberating Asia from the yoke of western imperialism. Some Japanese also esteem colonialism in Korea as a hothouse of modernization and progress, but this exculpatory narrative is a dead-end, one that infuriates Koreans and inflames the history wars.

\section{Rethinking Museums}

What role can museums play in engaging and shaping public discourse and attitudes towards the shared past? South Korea's history museums remain trapped in angry and accusatory narratives that allow for little nuance, commemorating colonial suffering and conveying a grim history of relentless Japanese depredations. It's a tale that needs telling and retelling because the Japanese have

\footnotetext{
${ }^{17}$ Interview Aug. 2014.

${ }^{18}$ Hatch (2014) reminds us that there are significant exceptions to this generalization. 
not been listening and have not done enough to confront the ghosts of the past. And so this past is endlessly excavated and mobilized. The evolution of the Seodaemun demonstrates, however, that there are possibilities of complicating narratives, making new connections and reexamining nationalist discourses.

Andrew Horvat who reported on South Korea from the 1970s as a journalist and worked as the Director of the Asia Foundation's reconciliation programs in the early 2000s, is somewhat optimistic that eventually the story of extensive Korean collaboration that currently stirs righteous moral condemnation will shift towards acceptance or at least a greater degree of toleration. He argues that,

anti-Japanese nationalism in Korea is so all-pervasive, so fierce and so universal because without it Koreans would have to confront the unacceptable reality of collaboration. This collaboration should not be seen in moralistic terms, but it is now. The fact is that Japan was the only game in town for Koreans, especially those like President Park's father, who were ambitious and wanted to get ahead. You either accepted Japanese rule, and used it to get ahead, or you stayed on the farm and ate barley.

As of 2014 the "barley eaters" narrative still appears to be in the ascendant as the politics of history portrays this choice as one between unalloyed Good and Evil, making it hard to imagine how collaboration can be decoupled from morality and repositioned as a practical (and widespread) accommodation to prevailing colonial realities.

Collaboration remains a dark space in Korean history because many of those who have exercised political and economic power in post-WWII South Korea were catapulted into the elite by their colonial-era experiences, and skills and networks developed under Japanese rule. This reality gnaws at the sanctimonious national identity that prevails. Yet "decriminalizing" collaboration might be a useful step towards reconciliation because it would open up new possibilities for collaborative research and museum exhibits featuring reconsideration of the shared history, drawing on intriguing progress in the realm of transnational colonial literature. (Kleeman 2003)

Morris-Suzuki (2009) suggests the possibilities of mingling national narratives, creating virtual spaces where,

...different narratives [can] be brought into contact with one another... allowing the light of [each] national narrative to illuminate the darkness of the others, and enabling the perspectives of the many victims ...to emerge from the shadows. 
It is an intriguing idea, but disseminating it may prove difficult.

For example, there is a digital museum about the comfort women that was compiled by the Asia Women's Fund and is translated into Korean, Japanese and English. (AWF 2007, Wada 2008) This virtual library upends the misleading narrative of Japan's collective amnesia, conveying important information about one of the festering wounds in bilateral relations. It contains reference materials, voices of some of the victims collected in an oral history project, memoirs of Korean comfort women, five volumes of documents collected by a government investigation and some videos. In short, it is an invaluable resource for teachers, researchers and journalists. But the AWF never got traction in South Korea and activists groups there discouraged former comfort women from accepting the proffered compensation because it was seen to be a Japanese government subterfuge to avoid taking direct legal responsibility and thus shirking the burdens of history. (Soh 2008) In the absence of rebranding, getting Koreans into the door of this museum may prove difficult.

My pessimistic conclusion is that the time is not ripe for reconciliation in museums, textbooks or other spaces for narratives of Korean-Japanese history and won't be for the foreseeable future. Much as mutual understanding is an alluring goal, and efforts towards this should be maintained, the pathologies of the past won't be overcome in the absence of sufficient government will to do so; here the signs are not encouraging. In South Korean democracy, there is very little room for compromise on colonial history and an irresistible temptation to score points for political gain at the expense of reconciliation. Japanese government officials and conservative politicians feel that sincere efforts such as the Kono Statement and AWF have been sabotaged and dismissed, and that their counterparts will never be satisfied, leaving them disinclined to pursue further reconciliation initiatives. It is unlikely that resilient grassroots ties can achieve what museums have not, because even as people in Japan and South Korea enthusiastically consume each other's popular cultures, visit each other's tourist sites and interact far more than before through various educational, cultural and civil society exchanges, the venomous backlash in both countries in recent years suggests that unshackling the present from the past remains a long-term project. 


\section{References}

ANN. 2014. "France's Angoulême Comics Festival Displays Comfort Women Manhwa." Accessed Aug. 13, 2014. http://www.animenewsnetwork.com/news/2014-0131/france-angouleme-comics-festival-displays-comfort-women-manhwa.

Ahn Jung-geun Memorial Hall website, translations by Hyun Sook Yun. Accessed Aug. 13, 2014. http://www.patriot.or.kr/.

Asahi. 2014. "One Piece exhibition held in Seoul after all." Asahi July 26. Accessed Aug. 13, 2014. http://ajw.asahi.com/article/asia/korean_peninsula/AJ201407260043.

AWF. 2007. Digital Museum. Accessed Aug. 13, 2014. http://www.awf.or.jp/index.html.

Choe, Sang-hun. 2007. 'Unearthing War Horrors Years Later in Korea.' New York Times Dec. 3. Accessed Aug. 13, 2014. http://www.nytimes.com/2007/12/03/world/asia/03korea.html?pagewanted=all\&_r=0.

Denton, Kirk. 2014. Exhibiting the Past: Historical Memory and the Politics of Museums in Post-socialist China. Honolulu, HI: University of Hawaii Press.

Denney, Steven, and Green, Christopher. 2014. "National Identity and Historical Legacies: Ahn Jung-geun in the Grand Narrative." Sino-NK June 6. Accessed Aug. 13, 2014. http://sinonk.com/2014/06/06/national-identity-and-historical-legacy-ahn-jung-geunin-the-grand-narrative/.

Dower, John. 2012. Ways of Forgetting, Ways of Remembering: Japan in the Modern World. NY: New Press.

Dudden, Alexis. 2005. Japan's Colonization of Korea: Discourse and Power. Honolulu: University of Hawai'i Press.

—. 2008. Troubled Apologies among Japan, Korea and the United States. NY: Columbia University Press, 2008.

—. 2010. "Memories and Aporias in the Japan-Korea Relationship." The Asia-Pacific Journal, 14-3-10, April 5. Accessed Aug. 13, 2014. http://japanfocus.org/-AlexisDudden/3337.

—. 2012. "Apology Laid Bare: Colonialism, War and Japanese Historical Memory." The Asia-Pacific Journal April 3. Accessed Aug. 13, 2014.

http://japanfocus.org/events/view/137.

Han, Jung-sun N. 2014. "Japan in the Public Culture of South Korea, 1945-2000s: The Making and Remaking of Colonial Sites and Memories." The Asia-Pacific Journal 12(15, 2), April. Accessed Aug. 13, 2014. http://japanfocus.org/-Jung_Sun-Han/4107.

Hatch, Walter. 2014. "Bloody Memories: Affect and Effect of World War II Museums in China and Japan." Peace and Change 39(3), July: 366-94.

Johnston, Eric. 2014. “Comfort Women Statues Spur Debate.” Japan Times Feb. 27. Accessed Aug. 13, 2014.

http://www.japantimes.co.jp/news/2014/02/27/national/comfort-women-statues-spurdebate/\#.U9yM2hziaA4. 
Keene, Donald. 2002. Emperor of Japan: Meiji and His World, 1852-1912. New York: Columbia University Press.

Kim Seong-ho. 2014. “Jeon-beom-gi Nol-lan Hae-gyeol-doen 'won-pi-seu' Jeon-si-hoe Ga-bo-ni-t (Visiting the One Piece Exhibition in the Aftermath of the Japanese Imperialist Flag Controversy).” Money Today News 29 July 2014. Accessed Aug. 13, 2014. http://news.mt.co.kr/mtview.php?no=2014072907391829886\&VMN.

Kingston, Jeff. 2007. "Awkward Talisman: War Memory, Reconciliation and Yasukuni." East Asia 24: 295-318.

—. 2008. "Nanjing's Massacre Memorial: Renovating War Memory in Nanjing and Tokyo.” Japan Focus, Sep. 2008. Accessed Aug. 5, 2014. http://japanfocus.org/ -JeffKingston/2859.

—. 2010. Contemporary Japan: History, Politics and Social Change since 1945. London: Wiley-Blackwell.

—. 2011. "Contextualizing the Centennial of Japanese Colonial Rule in Korea." Asian and African Studies 15(3): 71-94.

—. 2013. "Japan and Korea: Reconciliation and Redress for Wrongs Remain Elusive." Japan Times Sept. 28. Accessed Aug. 13, 2014.

http://www.japantimes.co.jp/opinion/2013/09/28/commentary/japan-and-koreareconciliation-and-redress-for-wrongs-remain-elusive/.

Kleeman, Faye Yuan. 2003 Under an Imperial Sun: Japanese Colonial Literature of Taiwan and the South. Honolulu: University of Hawai'i Press.

K-pop. 2013. Accessed Aug. 13, 2014. http://www.soompi.com/2013/05/01/t-ara-n4under-fire-for-using-japanese-imperialism-symbol-in-countryside-diaries-mv/.

http://netizenbuzz.blogspot.com.au/2013/11/troublemaker-apologizes-forwearing.html.

http://www.japancrush.com/2013/stories/korean-boy-band-wear-hats-with-rising-sunflag-in-video.html.

Levine, Brittany. 2014. "Lawsuit Seeks removal of Glendale 'Comfort Women' Statue." LA Times Feb. 22. Accessed Aug. 13, 2014.

http://articles.latimes.com/2014/feb/22/local/la-me-ln-glendale-comfort-womenstatue-sparks-lawsuit-20140222.

Morris-Suzuki, Tessa. 2009. "Remembering the Unfinished Conflict: Museums and the Contested Memory of the Korean War.” The Asia-Pacific Journal 29(4), July 27. Accessed Aug. 13, 2014. http://japanfocus.org/-Tessa-Morris_Suzuki/3193.

—. 2014. "Addressing Japan's Comfort Women from an Academic Standpoint." The Asia-Pacific Journal 12(9, 1), March 2. Accessed Aug. 13, 2014. http://japanfocus.org/-Tessa-Morris_Suzuki/4081.

Pillay, Navi. 2014. "Japan Urged to Provide Redress to Victims of Sexual Slavery." Accessed Aug. 13, 2014. http://www.unmultimedia.org/radio/english/2014/08/japanurged-to-provide-redress-to-victims-of-sexual-slavery/\#.U-Qi6BziamQ. 
Rausch, Franklin. 2013. "The Harbin An Jung-Geun Statue: A Korea/China-Japan Historical Memory Controversy." The Asia-Pacific Journal 11 (48, 2), Dec. 2. Accessed Aug. 13, 2014. http://japanfocus.org/-Franklin-Rausch/40400.

Saaler, Sven. 2005. Politics, Memory and Public Opinion: The History Textbook Controversy and Japanese Society. Munich: iudicum Verlag.

Sakamoto, Rumi, and Allen, Matt. 2007. "Hating 'The Korean Wave' Comic Books: A sign of New Nationalism in Japan?" The Asia-Pacific Journal Oct. 4. Accessed Aug. 13, 2014. http://japanfocus.org/-Rumi-SAKAMOTO/2535.

Schreiber, Mark. 2013. "Tabloids Brimming with anti-Korea Diatribes.” Japan Times Oct 12. Accessed Aug. 13, 2014.

http://www.japantimes.co.jp/news/2013/10/12/national/media-national/tabloidsbrimming-with-anti-korea-diatribes/\#.U-CJlxziamQ.

Selden, Mark. 2014. "Bombs Bursting in Air: State and Citizen Responses to the US Firebombing and Atomic Bombing of Japan." The Asia-Pacific Journal 12(3, 4), Jan. 20. Accessed Aug. 13, 2014. http://japanfocus.org/-Mark-Selden/4065.

Soh, C. Sarah. 2008. The Comfort Women: Sexual Violence and Postcolonial Memory in Korea and Japan. Chicago: University of Chicago Press.

Togo, Kazuhiko. 2014. "Obama Visit Fails to Strengthen US-Japan Trust.” East Asia Forum May 7. Accessed August 13, 2014.

http://www.eastasiaforum.org/2014/05/07/obama-visit-fails-to-strengthen-us-japantrust/

Tokudome, Kinue. 2007. 'Passage of H. 121 on 'Comfort Women', the US Congress and Historical Memory in Japan.” The Asia-Pacific Journal Aug. 30. Accessed August 13, 2014. http://japanfocus.org/-Kinue-Tokudome/2510.

Trends in Japan. 2014. "Breaking the Ice: South Korea Lifts Ban on Japanese Culture." Accessed Aug. 13, 2014. http://web-japan.org/trends98/honbun/ntj981207.html.

Wada, Haruki. 2008. "The Comfort Women, the Asian Women's Fund and the Digital Museum." The Asia-Pacific Journal Feb. 1. Accessed Aug. 13, 2014. http://www.japanfocus.org/-Wada-Haruki/2653.

Wakabayashi, Ippei. 2008. "Ahn Jung-geun and the Cultural Public Sphere.” Bunkyo daigaku kokusai gakubu kiyō 19(1), July: 157-63. Accessed Aug. 13, 2014. http://www.bunkyo.ac.jp/faculty/lib/slib/kiyo/Int/it1901/it190110.pdf.

White House. 2014. Accessed Aug. 13, 2014. http://www.whitehouse.gov/the-pressoffice/2014/04/25/press-conference-president-obama-and-president-park-republickorea.

Yoshida, Takeshi. 2014. From Cultures of War to Cultures of Peace: War and Peace Museums on Japan, China and South Korea. Portland, Me.: Merwin Asia. 